\title{
Cicero's children: the worth of economic history and economic thought for business students
}

\author{
Alex Millmow ${ }^{1}$ \\ University of Ballarat
}

A.Millmow@ballarat.edu.au

\begin{abstract}
'To be ignorant of what happened before you were born is to remain always a child'. Cicero
\end{abstract}

\begin{abstract}
Despite talk about the first sightings of the 'green shoots of recovery' the Global Financial Crisis which began to unfold in August 2007 is likely to exert some impact upon the prevailing economic and political philosophy. The big question for economic and business instructors is to ponder whether it will lead to any significant changes in economic and business syllabus at Australian universities. The teaching of mainstream economics is durable and usually resistant to change. Yet the crisis has certainly caused rumblings in the teaching of first-year economics. As one ABC reporter recently asked 'How do you teach economics at a time like this?' There is certainly a great curiosity among the young about what went wrong. Moreover they wish to know why neoliberalism has failed and why state interventionism is resurgent. Young minds must be perplexed about the rapid revision of agenda from containing inflation in 2008 to coping with recession in 2008. To paraphase the lyrics to the old Talking Heads song 'Once in a lifetime' 'You may ask yourself, well... how did we get here?' This is what they and we are asking themselves. This paper argues that an introductory course in economic ideas could help tell them why.
\end{abstract}

\section{INTRODUCTION}

Despite talk about the first sightings of the 'green shoots of recovery' the Global Financial Crisis (GFC) which began to unfold in August 2007 will certainly exert some impact upon the prevailing economic and political philosophy. As Rahn Emanuel, President Obama's Chief-of-Staff put it: 'You don't ever want a crisis to go to waste; it's an opportunity to do important things that you would otherwise avoid'. The big question, then, for economic and business instructors is to ponder whether it will lead to any significant changes in economic and business syllabus at Australian universities. How will the GFC be treated in the economic textbooks that are beginning to emerge? It has certainly caused rumblings in the teaching of first-year economics where principles like the efficient market hypothesis, rational expectations and the promised fruits of deregulation and free markets have been called into question by commentators. In a perverted sense it is a wonderful time to be teaching first year economics with student interest levels high.

Within academe there has been mostly silence about the impact of the GFC on economics teaching. The events of 2008 made teaching first year macroeconomics a little awkward in that what was happening on Main Street USA did not readily concur with what is said in the textbooks. As one ABC reporter pointedly asked me last October 'How do you teach economics at a time like this?' There is certainly a great curiosity among the young about what went wrong if the evidence of questions in

\footnotetext{
${ }^{1}$ Alex Millmow is a senior lecturer in economics at the University of Ballarat. He is also the President of the History of Economic Thought Society of Australia. I would like to thank JohnLodewijks for reading and commenting upon an earlier draft of this paper. I would also like to thank Geoffrey Blainey and Ian Macfarlane for their input used in the paper.
} 
economics classes reflect the views of their peers. Moreover they want to know why neo-liberalism has failed and why state interventionism is resurgent. Indeed, this may reinvigorate enrolments in economics subjects and economics majors at universities and at high schools, much as the Great Depression did for its generation of students.

It is often said, with a wry grin, that the worse the economy gets the better it is for economists. Young minds, too, may be perplexed about the rapid revision of the economic agenda from a focus on containing inflation in 2008 to aggressively intervening to cope with recession in 2009. In the United States we have Keynesian and Monetarist policy responses operating at the same time - something that would thoroughly confuse most first-year economics students, if not their instructors. This paper argues that only an elemental course in the evolution and historical development of economic ideas will tell them why. In underlining the value of the history of economic thought to the development of a student's understanding of economics, this paper will discuss what a course might look like and why some historical perspective in economic thought would equip students with the means to understand the world they will work in.

\section{THE GFC AND THE ECONOMICS PROFESSION}

A 'once in a lifetime' event according to Alan Greenspan, the GFC has provoked an avalanche of commentary and reaction. The GFC, now dubbed 'The Great Recession', has been instrumental in giving a key lesson drawing out the gulf between the mainstream and the dissidents. Controversy is good if it leads to more students and a cleaning out of the stables.

Apart from bankers, central bankers, ratings agencies and auditors coming under attack for perpetrating this financial crisis, the economics profession have been ridiculed for not predicting it and then offering two schools of thought in response to it. The magazine Business Week summed up this negative perception of economists in a cover story asking 'What good are economists anyway?' American macroeconomists were criticized for not predicting the crisis, differing in their view on what caused it and, thirdly, differing on the cure for the crisis. Moreover, their economic forecasting has been awry. The reputation of the economics profession has taken some blows though some of it has been self-inflicted.

This was patently obvious at the American Economic Association meetings at San Francisco in January 2009 where the profession's 'best and brightest' were dismally disappointing and contrarian in their analysis of the crisis. Paul Ormerod (2009) marked the inauspicious timing and contents of the AEA's brand new journal Macroeconomics by asking 'Have Economists gone mad?' It was in response to an opening paper stating that there was a synthesis among macroeconomists built upon a coherent intertemporal general equilibrium model. The undoing of 'the great moderation' has led to macroeconomists revisiting the debates of 70 years ago and giving the public the image of a divided profession between expansionists and restrictionists. Those who know the contours of economics might well ask 'Well, what's new? 'If anything, the GFC might just reinforce the 'intellectual sclerosis' that J.B. Condliffe's wryly suggests leads to a 'hardening of the categories' $(1974,55)$. But it is not just macroeconomics that is under fire. The insights of behavioural economics might come into the introductory microeconomics to explain market anomalies and irrational economic behaviour, while at the same time, complementing conventional economics.

There have even been calls from heterodox quarters notably Steve Keen (2009) and Edward Fullbrook, the post autistic economist, for a radical change in the economics syllabus that would involve ridding the first-year economics of 'toxic textbooks' which have been held responsible for the global crunch. Non-mainstream economists like Hyman Minsky, whose work is largely unknown to modern economists and students alike, are now being reevaluated and offer the promise of a richer insights into these crises. Even the Bank for International Settlements, hardly a bastion of radicalism, 
trumphets Minsky's approach in it's widely read Annual Report. Lord Skidelsky, Keynes' biographer has gone further with articles like 'The treason of economists' singling out the Chicago school out for providing the theoretical scaffolding that underpinned the whole fiasco of subprime lending to take place. However, we are also seeing a counter-revolution that is reasserting the 'old-time religion'. Most recently, the Australian adapters of Parkin's best-selling introductory economics text that has just been released say it is all the Federal Reserve's fault - echoing Friedman who held the U.S. Central Bank responsible for the Great Depression. It was faulty monetary policy - keeping interest rates too low- not greed or structural problems with financial markets, that caused the crisis and nothing in economics needs to change at all. ${ }^{2}$ Another argument from this camp blames principalagency problems and upholds that what we need is 'the right form' of regulation.

This view conflicts with the Chicago law and economics specialist, Richard Posner who suggests that the crisis was a systemic one, the product of economic agents following market signals, aided and abetted by low interest rates and deregulation. Yes, Posner concludes, there was a perfect storm but 'a storm of responsibility and reasonable decision-making'. ${ }^{3}$ He accuses the economic profession of 'being asleep at the wheel', too beholden to the Chicago school of self-stabilising markets. He concluded: 'We are learning that we need a more active and intelligent government to keep our model of capitalist economy from running off the rails'. ${ }^{4}$ The noted American economic historian, Barry Eichengreen (2009) agrees that 'The vast majority of the economics profession remained blissfully silent and indeed unaware of the risk of financial disorder' essentially because the profession was dominated with deductionism, sophisticated mathematics and econometric models. He essentially argues, though, that the profession were not constrained 'by the limits of scholarly imagination' but rather went for a partial and blinkered reading of the literature that supported the risk-taking that was going on. His article appeared in The National Interest and featured a front cover of sheep entitled 'Meet the economists!' On a different tack completely the great Paul Samuelson believes that the training macroeconomists received in the 1980s makes them unprepared to deal with events like the GFC. He wants to remind the modern day economics textbook authors like Mankiw that 'Macroeconomics - even with all of our computers and with all of our information - is not an exact science and is incapable of being an exact science' (Clarke, 2009).

Some commentators have advanced the thesis that the GFC was underpinned by what business schools teach their students. Business schools, in particular their MBA programmes, have also come under attack for perpetrating a culture that allowed exuberance, hubris and greed (Crittenden, 2009) and limited theoretical vision (Eichengreen 2009). You might add ignorance, too. In response, there have been recent calls from a few Australian Vice Chancellors and some business Deans for a renewed focus on ethics and to generally instill some social responsibility into business courses. This is usually complemented with a greater awareness of environmental sustainability issues including global warming and climate change issues. However the bread and butter of business education, subjects like accounting, management and economics would remain unaltered. Tim Brailsford, President of the Australian Business Deans Council has stated that following the fallout from corporate scandals like Enron and Worldcom, business schools have already inserted more units involving corporate social responsibility and sustainability. Brailsford and, Shirley Leitch, the Dean of Business at the University of Wollongong, agreed the GFC has 'legitimised the injection of social awareness into the business curricula'. ${ }^{5}$ The ABDC has been commissioned by the Carrick Foundation to address the challenges facing business education at Australia's 37 business schools. Economists can help here too since so many of us these days ply our trade in the business schools.

\footnotetext{
${ }^{2}$ D. McTaggart, C. Findlay and M. Parkin, 'The state of economics', East Asia Forum, website

3 J. Rauch, 'Capitalism fault lines', The New York Times May 17, 2009.

${ }^{4}$ Ibid.

${ }^{5}$ J. Gilling, 'In the wake of Stern and the GFC', Campus Review 14 April 2009.
} 
Before doing so we might ask whether this crisis will lead to changes in the university economics syllabus. Initial indications would suggest that university departments will not be moving away from the existing paradigm in a hurry. ${ }^{6}$ It will be business as usual. Cohen found that 'Free market theory, mathematical models and hostility to government regulation' still reigns in most American economic departments. This is understandable as academics protect their accumulated human capital (they do not want their assets to be made redundant) and as it takes a lag of several years before new texts come on the publishing market with all the add-ons now required for instruction (computer test banks, web sites, power-point slides). One of the best selling economic textbook authors Greg Mankiw stated that there would only be subtle changes to a first year principles course. He did nominate four areas requiring some revision or renewed emphasis. They were: the role of the financial institutions, the effects of leverage especially with banks, the limits of monetary policy and defending the reputation of economic forecasting. ${ }^{7}$ In other words, some tinkering at the edges is all that is required.

The intensity and speed of the GFC surprised many people, not least, the Federal Treasury's top economic modellers. ${ }^{8}$ One of Australia's eminent historians, Geoffrey Blainey, formerly Professor of Economic History at the University of Melbourne, relates the story of how SES executives within the Australian public service were totally surprised when he told them late last year that the boom usually ends in pain. ${ }^{9}$ In other words they had no conception of economic history. Blainey had drawn attention to the remarkable length of the boom in Australia and the Western world. Any long and strenuous boom comes to an end, usually with some pangs of pain or a loud bang. It was the same fiction, perhaps, that befallen the Treasury's economists who forecast that the mineral export boom would continue on with only a slight moderation in intensity. ${ }^{10}$ Treasury economic forecasts posit that the post-recession Australian economy will grow at 4.5\% per year from 2011/12 when, according to the Treasury's official history, the average Australian growth rate over the $20^{\text {th }}$ century was $3.4 \%$.

\section{GOING RETRO AND WHY IT MATTERS}

'History might not repeat but it does rhyme' according to the American story-teller Mark Twain. One of Australia's most eminent economists Max Corden (2007) told some graduating University of Melbourne students that 'We can only understand the present and form sound views about the future by knowing the past'. He spoke about how many of the problems encountered by China in its ferocious industrialization were replicated long ago by Britain and America.

If the mainstream will not markedly change due to the inertia that comes with intellectual investment we might ask whether there might be a renaissance in the areas of economic history and the history of economic thought. We could impart their work into a principles course or offer a completely new elective. There has certainly been a rebirth of interest in the works of Keynes, Hyman Minsky and Irving Fisher. There have also been comparisons made between the GFC and the Great Depression. Yet over the last twenty years these two disciplines have suffered a diminution in teaching weight in the traditional economics degree offered by Australian universities.

Currently, of the 27 Australian university economic departments only 13 or $50 \%$ of them offer history of economic thought (hereafter HET) or its equivalent as an elective and usually at a second or thirdyear level. ${ }^{11}$ The last survey, undertaken by John Lodewijks in 1995 (2002, 159) reported that HET

\footnotetext{
${ }^{6}$ P. Cohen, 'Ivory tower unswayed by crashing economy', The New York Times March 5, 2009.

${ }^{7}$ G. Mankiw 'The freshman course won't be quite the same', The New York Times May 23, 2009.

${ }^{8}$ P Cleary' Flawed forecasts: how Treasury misread a boom', Australian Financial Review April 28, 2009.

${ }^{9}$ Personal communication with the author, April 2009.

${ }^{10}$ Ibid Cleary.

11 They are: University of NSW, Murdoch, Monash, Macquarie, University of Western Sydney, ANU, University of Queensland, University of Western Australia, Notre Dame University, University of Melbourne, University of Sydney, University of Wollongong and Curtin University.
} 
was only taught in three out of six states in some twenty university courses. In some universities like the University of New England or La Trobe University the subject has languished because there is no longer an instructor to take the unit. Interestingly, despite its disproportionate weight in economic research and eminent economists (D.B. Copland, J.B. Condliffe, A.W. Phillips) not one of New Zealand's eight university economic departments offers a unit in the subject. It appears, too, that history of economic thought is barely taught at Australian business schools. In the United States, however, the subject does make some showing at business schools and also and much more successfully at liberal arts colleges (Dean and Dolan, 2001).

A comparable study of the economic degree structure in the United States showed that $82 \%$ from a sample of 148 colleges and universities offered the subject (Dean and Dolan, 2001, 32). There is moreover a thriving industry of HET textbooks to complement these courses which are taught in business schools and, most particularly, in liberal arts colleges tailored to the higher end of the market. For instance, seventeen of the top twenty liberal arts colleges in the United States offer a course in the history of economic thought (Bateman, 2002, 18). Students attending these colleges in America would be drawn from relatively high social economic status. The benefits of exposing students to HET are not in preparation for further study in the field per se but rather to meet intellectual curiosity, enlightenment and, more specifically, to aid in the development of critical thinking, analytical acumen and how to write and speak well (Bateman, 2002, 24-25). These are also highly prized attributes for any students, including business graduates, who might now be expected to have several careers in a lifetime.

The teaching or propagation of Australian economic history or economic history in general is in an even more dire state than HET with only a handful of university economics departments offering the subject. Ten years ago there were seven separate departments of economic history within Australian universities; today, there are exactly none (McLean and Shanahan, 2007, 301). As Geoffrey Blainey discovered, few students do economic history anymore. Previously, economic history graduates had the advantage of becoming 'all-rounders' with the ability to understand the trend of political and economic events because they were taught to see them as part of the long process of evolution. The American economic historian, Jeffrey Williamson recently said that too many Australian economic departments 'have not supported their economic history colleagues with enough posts to allow the sub discipline to survive'. ${ }^{12}$ Williamson said that economic history was in far better shape in American and Britain - a view shared by McLean and Shanahan (2007). Graeme Snooks of the ANU, now Australia's only research professor in economic history, backed what Williamson was saying that economic policymakers and planners needed a good understanding of economic history. Presumably he meant that economic graduates emerged without a skerrick of economic history, a sense of perspective about the dynamics of capitalism. In defense, it must be said, some economic historians or more accurately 'social historians' have divorced themselves from contemporary developments in economics and have thereby isolated themselves and appear less and less relevant to the discipline. It is the cliometricians - those economic historians using contemporary statistical and econometric tools - who are still highly valued. A similar argument can be made about historians of economics who are, at times, more comfortable in the company of the philosophy and history of science than in their own economics discipline.

Snooks' remarks did not find ready support in a survey of graduate economists working within the Australian Public Service undertaken by Ray Petridis in 1981. He found that economics graduates' exposure to economic history was only deemed as 'extremely useful' or 'very useful' by $7.5 \%$ of respondents while economic theory and analysis recorded a score of $64 \%$. That said, some $50 \%$ of the respondents did find economic history 'slightly useful'. The findings could not be attributable to age.

\footnotetext{
${ }^{12}$ G. Healy 'Economics must learn from its past', The Australian Higher Education Supplement 29April 2009.
} 
Most of the respondents in the survey had held an economics degree for at least twenty years or more (Petridis, 1981, 249). It gets worse for economic history. When asked what aspect of economics they would have liked to have more exposure to economic history was ranked behind economic analysis, quantitative methods, politics and government and computing. Contrast that finding with what Australian economic professors felt was the ideal regimen of the ideal economics degree. The professors gave HET and economic history a relatively high ranking that belies their standing today (Blandy, 1992, 29).

The former Governor of the Reserve Bank of Australia, Ian Macfarlane said the following about the worth of the two subjects:

'I regard both of these areas as being intrinsic to the study of Economics. As an economic policymaker during my years as Governor of the Reserve Bank, I came to rely more on the insights provided by the areas of thought. Unfortunately, I am entirely selftaught, as I never studied them at university. But as I became older (and I hope wiser) I delved into these areas and came increasingly to rely on them to help with practical policy decisions. At the end of my career, when I was chosen to deliver the 2006 Boyer lectures, I wrote what is essentially a piece of economic history, with a subtext which is the history of post-war economic thought, I felt this was of more use to understanding the current economic situation than any other approach, ${ }^{13}$

One clear lesson that comes out of this boom-bust of thinking about the teaching of economics is that those without any financial and economic literacy have suffered. Just ask the gullible investors with the Queensland investment trust Storm Financial or the young married couples rushing headlong into the property market in order to access the first home buyers grant.

In their book Animal Spirits Akerlof and Shiller (2009) relate how during the boom brokers and share market boosters would become storytellers and tell investors that this was the 'new economy' and that the bull market would continue and that the business cycle had been banished. People swallowed the stories whole, unaware that property prices and stock market prices can fall and fall markedly. A little bit of HET, if not economic history, would have told them otherwise. We are seeing the same pattern of ignorance with the Rudd government's deficit financing making many fearful of public indebtedness. In the past students were told that public debt does not really matter as the financing of a modest budget deficit simply means the reallocation of wealth among the Australian community. A deficit budget, too, of course is quite defensible when demand from the private sector lapses. We seem to have forgotten the doctrine of functional finance of Abba Lerner.

\section{WHAT EDUCATIONAL VALUE DOES HET ACTUALLY BESTOW?}

Jacob Viner used to say that 'Economics is what economists do' (Condliffe, 1974, 12). Some call economics a science, others an art. In the Stephen Sondheim musical 'Sunday in the Park with George' there is a song 'Putting it together' with the lyrical refrain 'Art isn't easy'. We might well say the same about economics, especially in its application.

While there is occasional discussion about the place, viability and relevance of the HET within the economics and business faculty, an event unfolded in Australia in August 2007 that brought much of the argument to the ferment. The date, of course, was rather ironic given that it marked the onset of the sub prime crisis in the United States with major financial institutions on the brink of insolvency.

\footnotetext{
13 This quote is used with the kind permission of Ian Macfarlane.
} 
The Australian Bureau of Statistics (ABS) had undertaken a revision of its research classifications in particular the Australian Standard Research Classification following a request from the Department of Education, Science and Training. The key proposal was to remove from the Economics research classification the fields of History of Economic Thought and Economic History. Under the new classification, research in HET and Economic History would no longer be recognized as economic research by the ABS and other Government departments. Rather it would be recorded as research activity in 'History, Archaeology Religion, and Philosophy' which, in Australia, is usually found in the Faculty of Arts where HET scholars are not employed. As long as universities and Government departments, including those bodies which fund academic research, used the revised research codes then the HET and Economic History would be effectively removed from economics departments, their natural home. Like everywhere in academe, it is on the basis of publications, of course, that conference funding, promotion and, indeed, job openings depend. It would mean, then, that HET scholars along with economic historians working in economics departments would have to change their research orientation to save themselves from retrenchment or attempt to transfer to the Arts faculty where their research quantum would be both enumerated and valued. HET scholars and economic historians rushed to remind their colleagues in the economics faculty that their subjects were an integral part of economics. Kates and Millmow (2008) discerned seven benefits which an exposure to HET would bring to the student and economist alike. They were

1. HET is a pathway to understanding economic theory and its application

2. HET provides a perspective on existing theory that provides orientation for its future development

3. HET is a conversation with the economists of the past on contemporary questions

4. HET is a storehouse of theoretical approaches for dealing with economic issues

5. HET is a means of deepening one's understanding of contemporary theory

6. HET provides a literary approach to dealing with economic issues different from but as valid as mathematical and statistical approaches

7. HET is a means for training applied economists.

Kates and Millmow argued that an economist without background in HET is less well-equipped than one who does have such knowledge for dealing with straight-forward economic questions. While all seven have relevance to economics instruction we touch briefly upon four. First, HET can be used as a guide to understanding economic theory and its application. HET has had a long history as a teaching tool. Economists have almost from the start looked backwards to earlier times to find contrasting approaches to dealing with economic questions. As J. K. Galbraith $(1987,1)$ put it 'There can be no understanding of economics without an awareness of its history'.

Adam Smith in The Wealth of Nations contrasted his view of the conditions under which economies would best perform with the mercantilist doctrines of his predecessors. Another long-time staple of the classroom has been the story of the Keynesian Revolution in which "classical" economic theory is shown to have been superseded by 'the new economics' of 1936. Students, in similar fashion, are taught the Marginal Revolution, where a comparison between the concept of total utility employed by earlier theorists gave way to an analysis that concerned itself with the addition to value of the last item bought. Marshall in his Principles repeatedly referred to economists of an earlier time in discussing 
various topics. What these represent are examples of HET as a means of explaining modern theory by comparing it with the theories of the past.

The reason for such an approach is fairly straightforward. Putting two (or more) theories side by side for comparison provides a background frame of reference. One of the theories is considered better, more complete, more encompassing while the other is seen as inferior, less complete, not as useful. In understanding the difference between the two, the features of the later, favoured theory are clarified and brought into focus.

This is in many ways the traditional use for HET. It is to employ the "mistaken" theories of the past as a background against which to understand modern theory. Mark Blaug in his path breaking Economic Theory in Retrospect makes that point in the very first sentence of his preface:

"This book is a study of the logical coherence and explanatory value of what has come to be known as orthodox economic theory. The history of this body of received doctrine goes back at least as far as Adam Smith. I am not concerned, however, with historical antecedents for their own sake. My purpose is to teach contemporary economic theory.” (Blaug, 1968, ix)

There is nothing in any of this that denies that even the most modern up-to-date theory will not itself one day be held up as an example of some woebegone half-truth, mistruth or outright error. It is merely a device for allowing those being taught in the here and now to appreciate in finer detail what is modern by seeing it against what has been transcended. In seeing the differences, a learning process takes place. By holding up for examination what are considered mistaken theoretical approaches for dealing with particular economic issues, the various aspects of what should be avoided are brought to light. We use the theories of the past as a framework in which to highlight the features of the new.

The singular utility of HET as a means to understand economic theory is tacitly acknowledged in the literature reviews included in most doctorates. One therefore implicitly makes it clear that this is how economists learn to be economists. We learn from watching how others had grappled with similar problems in the past. We recognise that before one can make a fresh contribution of one's own, we must have understood what contributions others have already made before.

Relatedly, we can use HET as a guide for the development of theory. Dissatisfaction with whatever happens to be the mainstream theory of the time has been a perennial issue for as long as economics has been studied. But theory is never just a settled body of conclusions. It is always and everywhere the conclusions themselves along with the process of having reached them. The history of the development of the theory is itself an important ingredient in understanding what those theories mean in practice, as well as being part of the typical methodology in advancing beyond whatever conclusions are the reigning paradigm of the moment.

Economists regularly use theories of the past to frame issues for the future. Undoubtedly the most famous instance is Keynes's discussion of classical economic analysis in paving the way for the introduction of his own theoretical approach. Without the background history such an approach cannot be adopted. Without knowing the history oneself, a listener cannot gauge the accuracy of what is being said. A familiarity with the history of economics should therefore be recognised as an intrinsic part of the necessary knowledge base for anyone thinking about theoretical issues.

A third benefit of HET is that it allows the inclined student to study some of the finest writers in the history of our subject. Their rhetorical abilities are, in many ways, the reason that it is their work that has influenced later generations. Those who can establish their points most clearly are best able to carry others along with them. The ability to write well and to inspire has had an undoubtedly important influence on the direction that economics has taken. 
Studying the great economists of the past might just develops one's writing skills or at least writing about economics. HET specialists typically handle theoretical questions but in doing so learn to explain in words and concepts, an extremely important skill too often downplayed with modern economics generally.

Lastly, HET help generate a better corps of economists. In reality, economics is a policy science whose ultimate role is to provide a sufficiently deep theoretical understanding of the structure of economies to allow for the making of sound economic decisions. To underestimate the powerful role of studying HET in the training of economists is to misunderstand the way in which economists can and do become economists.

In Australia we have gone from teaching HET to virtually all economists to now teaching it to a handful meaning a very important component in the education of an economist has disappeared. It is, of course, rare that any practising economist will ever be asked to settle a question in the history of theory but they are asked instead to come up with useable answers to often very difficult real world problems. The contention here is that those who have studied the history of theory are able to access a wider range of answers and are better able to think outside the necessarily more narrow confines of whatever the reigning paradigm of the present moment happens to be.

\section{TWO PROPOSALS}

Most business students end up undertaking only two introductory units in economics. Some go on to do a major in economics but it can be safely assumed that economic history and the history of economic thought will not be on the agenda. The time is right for some historical perspective.

The matter of introducing first year students to some HET is hardly new. Some textbooks have pen portraits of the major economic theorists. Paul Oslington went one better by introducing an HET narrative into his first year course over the first 12 lectures of his unit offered at the Australian Defence Force Academy. He did this to show how economics was shaped by historical forces and by its relationship to philosophy, theology and politics. His unit description promised to develop 'a sound grasp of basic economic theory', 'developing skills in applying economic theory' and permit 'an appreciation of the limits of economics' (Oslington, 2002, 160).The syllabus is shown in Attachment A. Oslington felt the experiment a success in maintaining undergraduate exposure to history of economic thought, and helping to arrest the drift of students away from economics courses. One caveat with the experiment was that the model might only appeal to high calibre students and might not be easily replicated. As Oslington (2002. 161) notes 'Quality of students may well be the biggest problem in trying something similar at other Australian universities'. Time and space constraints in the syllabus were other problems; the danger of swamping the students with too much material is very real.

An easier expedient perhaps is the idea to expose business students to an introductory unit that focused exclusively on a panoramic, narrative sweep of economic thought from Adam Smith through to the Chicago school. There was a unit like this taught at Charles Sturt University in the early 1990s. It was offered to arts students (See Attachment B). It is possible such a unit could be taught to those undertaking an economics major in business schools. We could assuage any likely opposition from business school colleagues by having a purview of some of leading business thinkers like Peter Drucker and Michael Porter. 


\section{CONCLUSION}

Barry Eichengreen (2009) pointedly reminds us that the GFC was not meant to happen. The great moderation was akin to those who used to say they had tamed the business cycle and condemned the misery index to the scrapheap. The spirits who inhabit the graveyard of economic ideas are still revolving around. Exposing economics and business students to some HET would show them the richness of our discipline, its false turns, and guard against developing a sense of false invincibility. A little more skepticism about free markets theory and more exposure to the mayhem financial markets can inflict would be welcome improvements to the syllabus. Our students would be a little more savvy about how the economy works.

\section{REFERENCES}

Akerlof, G. and R. Shiller, 2009, Animal Spirits, Princeton University Press.

Blaug, M. 1968, Economic Theory in Retrospect, Cambridge University Press.

Anderson, M. and R. Blandy 1992, 'What Australian Economic Professors Think', Australian Economic Review, 25, pp. 17-40.

Bateman, B. 2002, 'Sitting on a log with Adam Smith: the Future of the History of Economic Thought at the Liberal Arts Colleges', in E.R. Weintraub (ed.) The Future of the History of Economics, Duke University Press: Durham, pp.17-34.

Condliffe, J.B. 1974, Defunct economists, Pegasus Press: Christchurch.

Crittenden, S. 2009, 'MBA: Mostly bloody awful', Background Briefing ABC Radio National, 29 March.

Clarke, C. 2009 'An interview with Paul Samuelson', The Atlantic web site June

Corden, M. 2007. 'Guidepoints for your future success', Insights 2, October.

Dean, D. and R. Dolan 2001, 'Liberal arts or business? Does the location of the economics department alter the major?', Journal of Economic Education, 32(1), Winter pp, 18-35.

Eichengreen, B. 2009, 'The Last Temptation of Risk', The National Interest, May/June.

Galbraith, J.K. 1987, A History of Economics, Penguin: London.

Kates, S. and A. Millmow, 2008, 'A Canary in the Coalmine: The Near Death Experience of History of Economics in Australia', History of Economic Ideas, XVI, 2008/3, pp. 78-94.

Keen, S. 2009 'Mad, bad, and dangerous to know', Real World Economics Review 49. pp. 2-7

Lodewijks, J. 2002, 'The history of economic thought in Australia and New Zealand ' in Weintraub, E.R. (ed.) The Future of the History of Economics, Duke University Press: Durham, pp. 154-164.

McLean, I. and M. Shanahan, 2007, 'Australasian Economic History: Research Challenges and Big Questions', Australian Economic History Review, 47(2) pp. 300-321.

Ormerod, P. 2008, 'Have Economists gone mad', The Atlantic March

Oslington, P. 2002 'Teaching economics historically’, History of Economics Review, 36 Summer, pp.160-164.

Petridis, R. 1981 'Economic Degrees and the Australian Public Service: A Note’, Australian Journal of Public Administration, 40(3) pp. 246-253.

Posner, R. A. 2009 A Failure of Capitalism, Harvard University Press. 


\section{ATTACHMENT A}

\section{Copy of Paul Oslington's draft of the course content for first year economics at ADFA.}

\section{Topics Covered}

\section{Topic 1 Introduction}

- Changing conceptions of economics. We consider various definitions offered by Smith, Senior, Whately, Robbins, Becker, Mankiw and Viner. The Australian adaption of Mankiw's textbook is used for the remainder of the first-year course and this discussion contextualises his view of economics.

- Critics of economics, from Carlyle and Tawney in nineteenth-century Britain, to Michael Pusey in twentieth-century Australia.

- Why study economics? Keynes's views about the influence of economists, and the intellectual challenge of economics. Joan Robinson's view that we study economics to avoid being misled by economists.

\section{Topic 2 Before Adam Smith}

- $\quad$ Aristotle and the Medieval Scholastics

- Hobbes, Petty, Locke and some moral philosophers who grappled with the problem of selfinterest and social order.

- Mercantilism

- Physiocrats

\section{Topic 3 Hume and Smith}

- The division of labour

- Value, distribution and growth

- The natural system of liberty and the invisible hand

- $\quad$ Smith on policy

Topic 4 Malthus, Ricardo and Mill

- The principle of population

- $\quad$ Ricardo’s corn model as an example of an economic model, and its policy uses.

- Utilitarianism

- Mill's 'homo economicus'. In this lecture we were privileged to receive a visit from 'homo economicus' himself. The dusty Victorian gentleman staggered into the lecture theatre and was interviewed about his approach to life.

\section{Topic 5 Marx}

- $\quad$ Reactions to Marx, and the relevance of the fall of the Soviet Union to an evaluation of Marx.

- Historical materialism and ideology

- Marx's analysis of capitalism

Topic 6 The Marginal Revolution and Marshall

- Marginal analysis

- Supply and demand analysis

- Economics and policy 


\section{Topic 7 Keynes}

- Keynes's rejection of the 'classical view' and the principle of effective demand.

- $\quad$ Events and ideas in the development of economics

\section{Topic 8 Twentieth Century Economics}

- A (too) brief overview of work for which economists have won Nobel prizes.

- The economics profession and the state of economics today. 